\title{
ECONOMIC EFFECT OF SHORT-TERM PERIOD TAX BENEFITS IN MOUNTAINOUS PARTS OF GEORGIA
}

\author{
Ketevan Tchanidze ${ }^{1}$, Doctor of Economics/Asistant of BSMA; Natela Tsiklashvili ${ }^{2}$ Doctor of \\ Economics/Professor of BSU; Zeinab Surmanidze ${ }^{3}$, Doctor of Economics \\ ${ }_{1,2,3}$ Batumi Shota Rustaveli State University
}

\begin{abstract}
Migration processes of high mountains and population growth of cities have led to depopulation in mountainous regions, rising unemployment in the city and a had a decrease in agricultural products, ultimately provoke external migration processes. These problems are typical not only for Georgia but also for the postSoviet countries and are relevant in the global context. The purpose of the study was to identify and analyse the effects of the short-term tax privileges for the mountainous regions of Georgia. The paper is dedicated to research and quantitative analysis of the impact of tax and social benefits on improving demographic conditions and regulating internal migration processes, both in the short and long-term perspective. The research methodology was based on the statistical processing of the survey results. For quantitative research, we used a structured questionnaire, which was developed by face-to-face interviews. Approximately 500 respondents were interviewed in 79 villages of 11 communities of Khulo, the Adjara Autonomous Republic, Georgia. The study revealed that by regulating tax and social benefits, it is possible to partially manage the internal migration processes of the mountainous region in the short run, while in the long run, a complex approach to the issue is important. In the mountainous parts, tax, social and other benefits will have a positive economic effect in the short term. Increasing the amount of income for individuals and legal entities is one way to stimulate the rural economy.
\end{abstract}

Key words: migration, economic demography, taxes

JEL code: R23

\section{Introduction}

For Georgia, as well as for many other countries around the world, the control of internal migration processes is an important problem ("Problems with demography and sociology", 2017). Emptying villages due to economic and social conditions has the negative impact on the country's economic parameters and demographic security. The population moving to the city is competing on labour market with the city's population that increases the number of unemployed residents and the rate of external migration, which ultimately poses a major threat to the country's normal development (Totadze A., 2012). In our opinion, another negative factor, which is also related to internal migration, is the so-called "Brain drain". A talented, hard-working worker who can't find a job either in the village or the city, has to go abroad and look for the right job for his skills and abilities. The Highlands of Georgia are distinguished with such talented, clever and purposeful young people, but because the village lacks production, there are no jobs. Thus, young people who are well educated in the city, cannot find the jobs relevant to their skills and abilities. They no longer think of returning to villages and prefer to live in the city or work abroad.

Our country has been suffering from this problem since the 1990s of the last century, and despite a number of different activities, emptying of the villages still continues (Tsuladze G., 2016). The economically active population of the village comes to the city and as a result of our surveys the number of rural populations reduces every year (Tsiklashvili N., Tchanidze K., 2019). The Georgian government has always paid attention to this problem. Taxes and social benefits have been imposed on the mountains to improve the demographic improvement and to halt the internal migration (Law of Georgia on Development of Highland Regions (in Georgian)).

\footnotetext{
${ }^{1}$ Ketevan Tchanidze e-mail: ketevan.tchanidze@bsu.edu.ge

2 Natela Tsiklashvili e-mail: natia.tsiklashvili@gmail.com

3 Zeinab Surmanidze e-mail: zei-surmanidze@hotmail.com
} 
The practice of tax exemptions for highland regions has been successfully applied in many countries around the world. The purpose of establishing such benefits is essentially the same in all countries, but the results may vary depending on the country.

For example, the Latvian government also applies tax incentives to increase economic and social well-being. According to Uldis Rutkaste (Economist of the Bank of Latvia), the volume of tax benefits in Latvia is 2.5 billion Euro is a year. However, Latvia intends to revise legislation on benefits. Latvia also has three free economic zones and two free ports. Taxes in Free Ports and Special Economic Zones regulate the use of direct and indirect tax privileges in special economic zones. Several countries in the world have tax exemptions on enterprises that produce goods and services in the highlands, such as Canada, Argentina, Greece, Zambia, Mozambique, Oman, Fiji. These countries have different rates and benefits for entrepreneurs and for the population - children and retirees. In Canada, tax benefits are enjoyed in the mountainous region of Yukon, Alberta Province (SPLASHdb.eu, 2015)

The present paper discusses the short-term effects of the tax benefits imposed on one of the mountainous regions of Georgia, the existing problems and ways to solve them.

\section{Research methodology}

For the study, we selected entrepreneurs registered in Khulo, one of the mountainous regions of Georgia, and conducted a survey. The study included two components: quantitative and qualitative. Qualitative research analysis includes types of business entities, income, level of satisfaction with tax benefits, opportunities for expanding entrepreneurial activity. For the quantitative research method, we used a structured questionnaire, which was completed by the face-to-face interview method. The questionnaire with its structural content consists of open and closed questions. It was possible to provide several answers to several questions. Research methods included oral history and observation. In the process of filling in the questionnaire, respondents were able to identify the problems they were facing and their problem-solving vision. Two groups of researchers were conducting face-to-face surveys in 79 villages of the Khulo Autonomous Republic, 79 villages. About 500 respondents, including legal and natural persons, were interviewed.

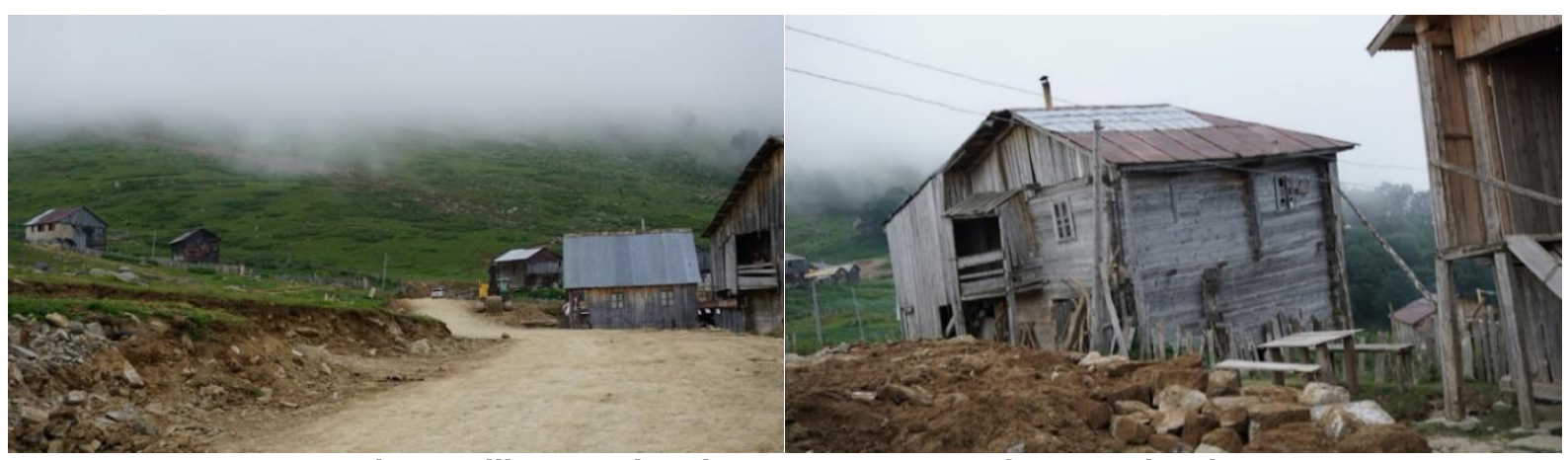

Photo. Village Beshumi 1850-1900 meter from sea level

\section{Research results and discussion}

On 16 July 2015 the Parliament of Georgia approved the Law on Development of Highland Regions. The purpose of this law is to identify benefits to stimulate the socio-economic progress of the mountainous regions, which will ensure the well-being of people living in the highlands, raising their living standards, promoting employment, improving their social and economic status. A person permanently residing in the Highlands is entitled to income and property tax benefits under the Tax Code. In addition, an entrepreneur who is granted the status of a high-mountain settlement 
enterprise under the legislation of Georgia shall be exempt from taxation for the term and in accordance with the Tax Code of Georgia (10 years from granting status). Within the limits of our research we searched for entrepreneurs registered in Khulo, one of the mountainous regions of Georgia and sought to find out the motives for their economic activity, their economic status, the effects of the "Mountain Law" and future development prospects. As it turned out, there are about 210 (National Statistic Office of Georgia, 2020) businesses in this region and their main areas of activity are: beekeeping, retail sale, fruit, citrus, subtropical crops, vegetables, herbs, technical crops, cereals, orchards, legumes, mushrooms, oily crops, grapes, milk and dairy processing, market (bazaar), planting material, seed processing, veterinary drug processing, agrochemicals, veterinary pharmacy, zoo shop, veterinary medicine, meat and meat products, milk and dairy products, flour products, food additives, food fortifiers, spices, animal food, animal food additives, cattle, eggs, flour and flour products, biscuits, chocolate, sugar, tea, coffee, non-alcoholic beverages, mineral water, ready-made foods, culinary products, oil, margarine, mayonnaise, confectionery, other public catering facilities: Khachapuri bakery, alcoholic drinks, primary production and packaging of agricultural poultry.

About 500 respondents from the Khulo municipality of Adjara were interviewed. Most of the interviewed entrepreneurs are granted high-mountain settlement enterprise status (68\%), only a small proportion do not have this status (32\%). The reason why enterprises that operate in Khulo do not have this status may be that some are waiting for status to be granted, but some of them do not meet the criteria set by law. One of the most important criteria is that business owner has a permanent resident status in the mountainous region. If the owner of the business does not have this status, then the enterprise established by him will not receive this status. Despite these limitations, there are quite a number of law firms in the Khulo municipality that carry out entrepreneurial activities for profit. Most of the enterprises surveyed operate all year round (77 \%), some seasonally $(23 \%)$. Almost all of them are familiar with Mountain Law (92\%) (8\%). The benefits provided by law: profit tax, property tax, income tax are enjoyed by most of them (40\%). Companies report their monthly income of GEL ${ }^{1} 1501-2000$ (61\%), GEL 2000 (more than $29 \%$ ), GEL $1001-1500$ (8\%), GEL 501-1000 (2\%) and none of them earn less than GEL 500. Most of the interviewed entrepreneurs believe that the economic situation of their enterprise has improved as a result of the enactment of the "Mountain Law" (69\%), with some abstaining from answering this question (29\%). The year of establishment of these enterprises is significant, the majority of which have been registered for the last 4 years, i.e. since the launch of the state-run Entrepreneurship Support Program "Produce in Georgia". To use this program, they were instructed to obtain legal status.

The number of employees in companies varies between 1-25 and the monthly income of employees is GEL 101-500 (77\%), GEL 501-1000 (21\%), GEL 1001-2000 (2\%). Given the fact that their employers have a benefit in the part of income tax, employees receive the above salary without deduction. Part of the survey results is presented in figures 1-8.

In the fourth year after the entry into force of the "Law of the Mountain", its effects are visible. From the data analysis of the survey, we came to some important conclusions.

- Motivation to start an entrepreneurial activity.

${ }^{1}$ GEL - Georgian Lari 
- The number of illegal, unregistered companies has been reduced by the requirement of compulsory registration. Companies no longer have a motive to do business without registration. To get the benefits, they only need to register and get a Highlander Enterprise status. Entrepreneurs are tax-exempt for 10 years after starting a business, which is a great time to raise capital and motivate new businesses.

- Creating jobs. Every company employs at least one person. If you look at the number of existing companies (210 operating companies) we can conclude that at least 210 jobs are created. The growth trend is expected in the future.

- Since the Law of the Mountain promotes the mobilization of the income on the site, this will result in the reduction of vulnerable families and the savings the state spends on subsidizing vulnerable families.

- According to the poll, also as a result of the interviews taken at the site, we believe that the tax losses are negligible compared with the social and economic effects of the law. Moreover, it can be assumed that the long-term social and economic effects will exceed tax losses, because this law creates the income at the place, improves the material conditions for the population, which in turn will lead to the improvement of socio-economic conditions and in this case the state budget expenses that it has in the form of different social insurances and assistance, will be reduced.

- However, it should also be noted that the Law of the Mountain may have quite different results in the short and long term. The law has two goals: mobilizing income at the site and consolidating the population in the mountains. The research has shown that the first purpose of the law is in the process of implementation, only a short time has passed, but the effect of income mobilization is evident, which is confirmed by the population survey. As for the second goal, it is still difficult to say anything at this time, however, depending on the sentiment of the population and considering one of the principles of economics that people respond to incentives and save part of their income, we may expect that the desire of welfare improvements will outweigh the benefits of income and they will still decide to move to the city to improve their living conditions and stay in the village only seasonally. As a proof of this, it can be said that nowadays the wealthy part of the population has already sent their children to the city because of better conditions, better education and career.

- It can also be concluded that in the long run only the improvement of living conditions and infrastructure can increase population in the mountains. Residents in many villages are still suffering from road, water, heating and other household problems. So, they are trying to get their children to live in better conditions and to help them stay in town. Everyone has the right to live in a comfortable environment and no high-mountain population is an exception. 


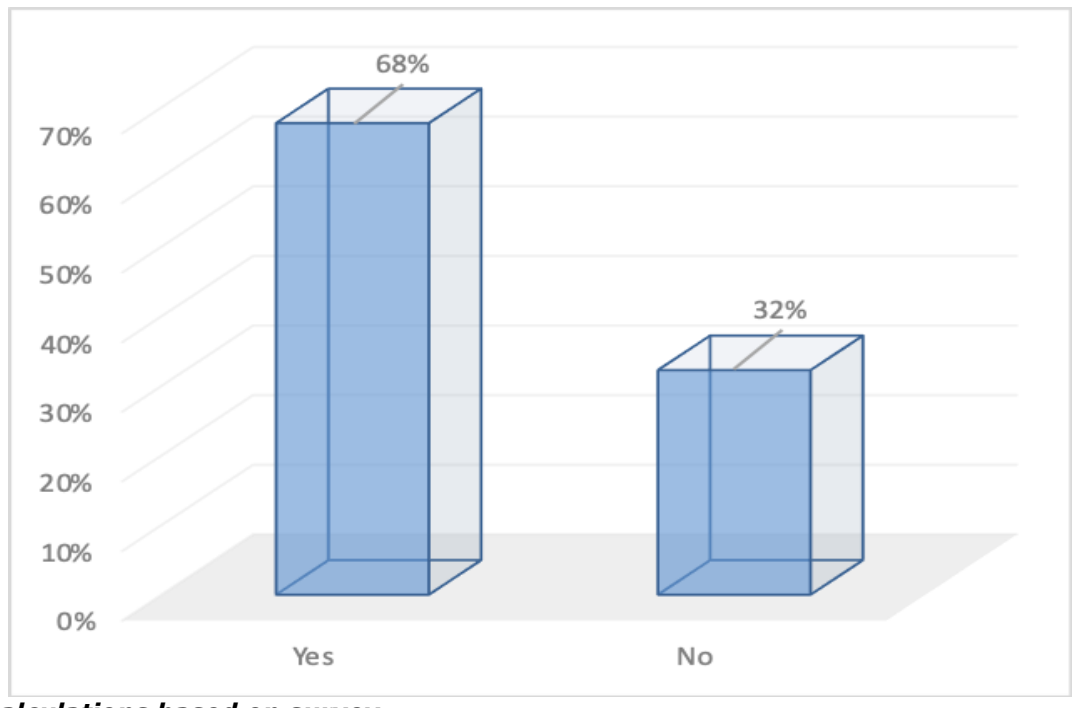

Source: author's calculations based on survey

Fig. 1. Question 1. Do you have Highland Settlement Enterprise status?

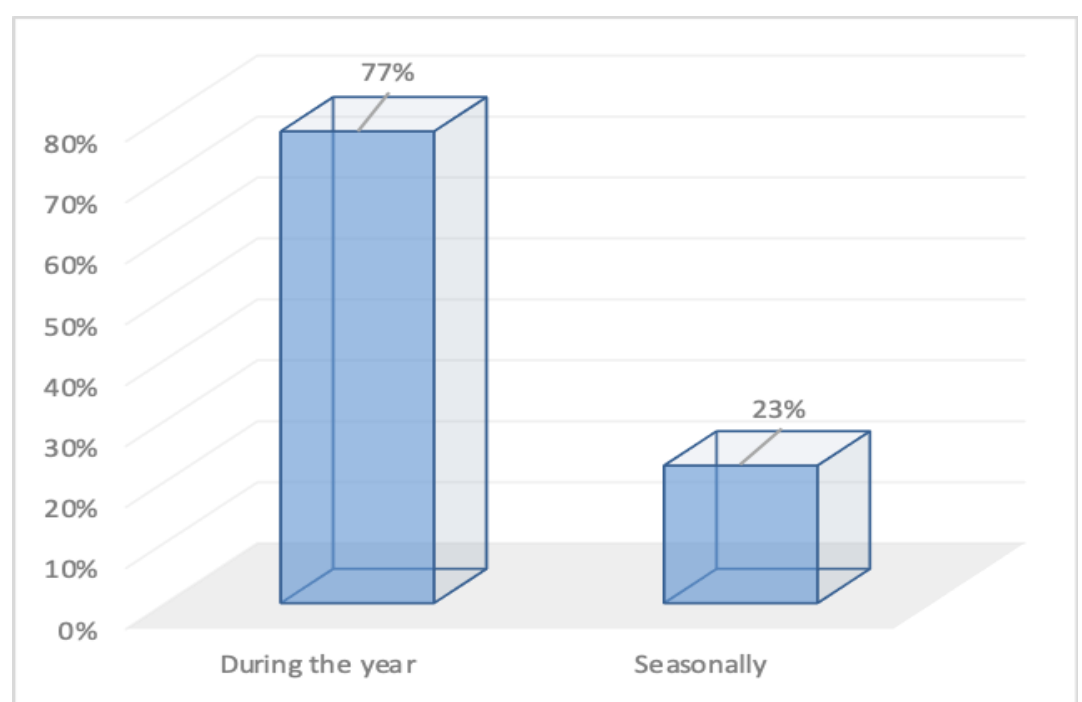

Source: author's calculations based on survey

Fig. 2. Question 1. Period of activities

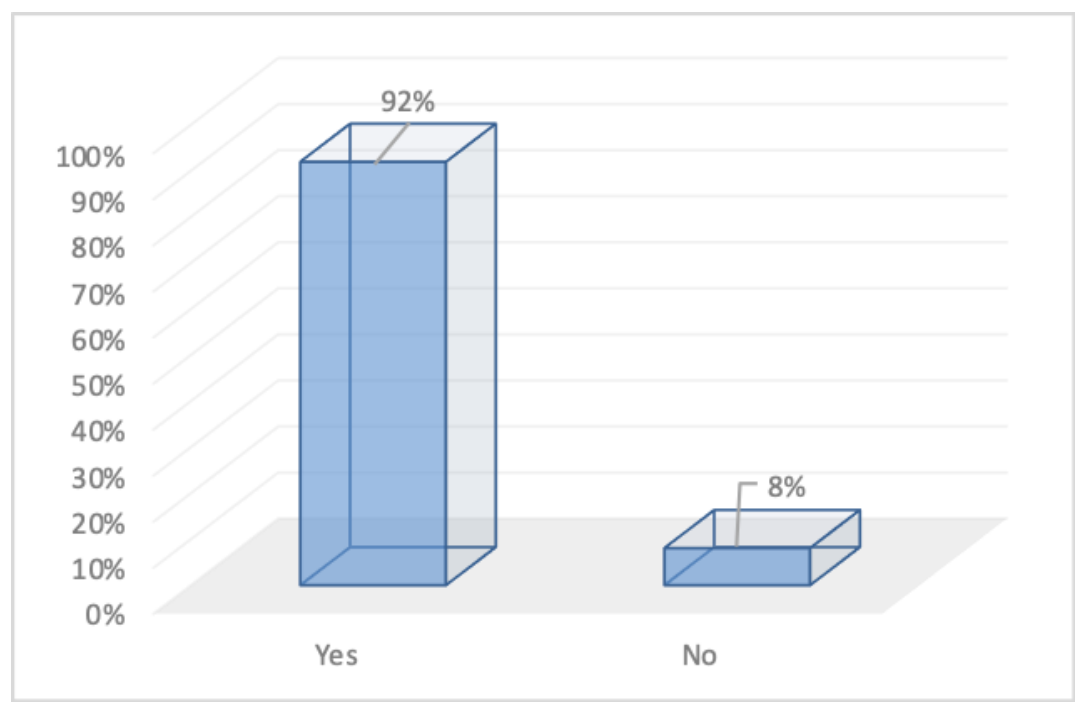

Source: author's calculations based on survey

Fig. 3. Question 3. Do you know the "Law of the Mountain"? 
Source: author's calculations based on survey

Fig. 4. Question 4. Which of the following tax benefits do you enjoy within the "Law of the Mountain"?

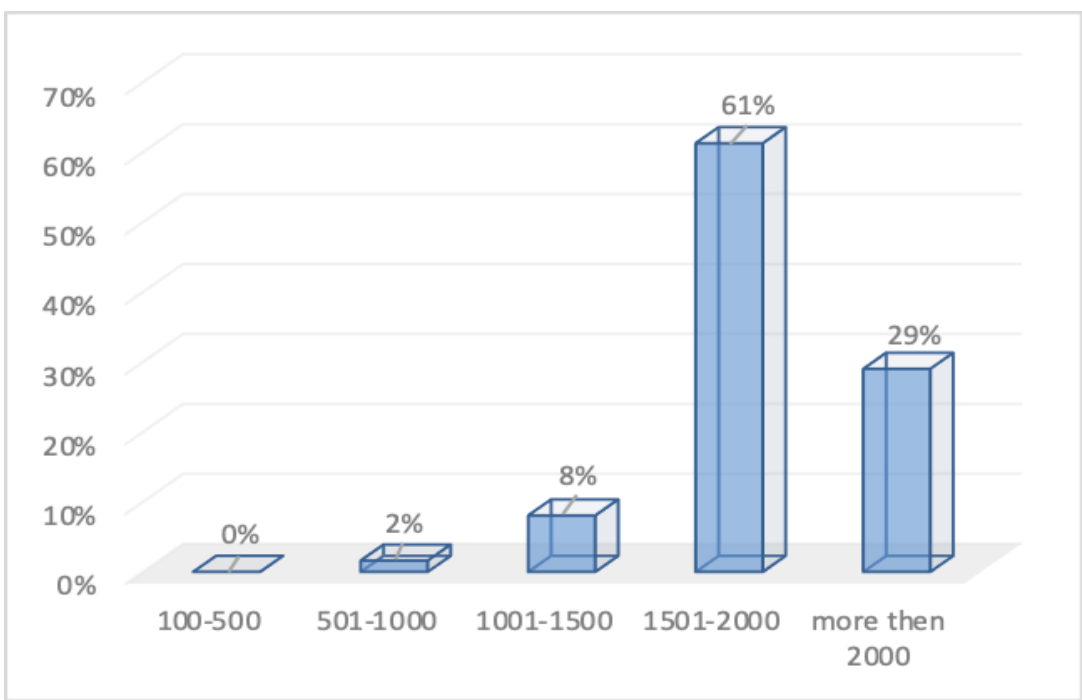

Source: author's calculations based on survey

Fig. 5. Question 5. How large is your company's income?

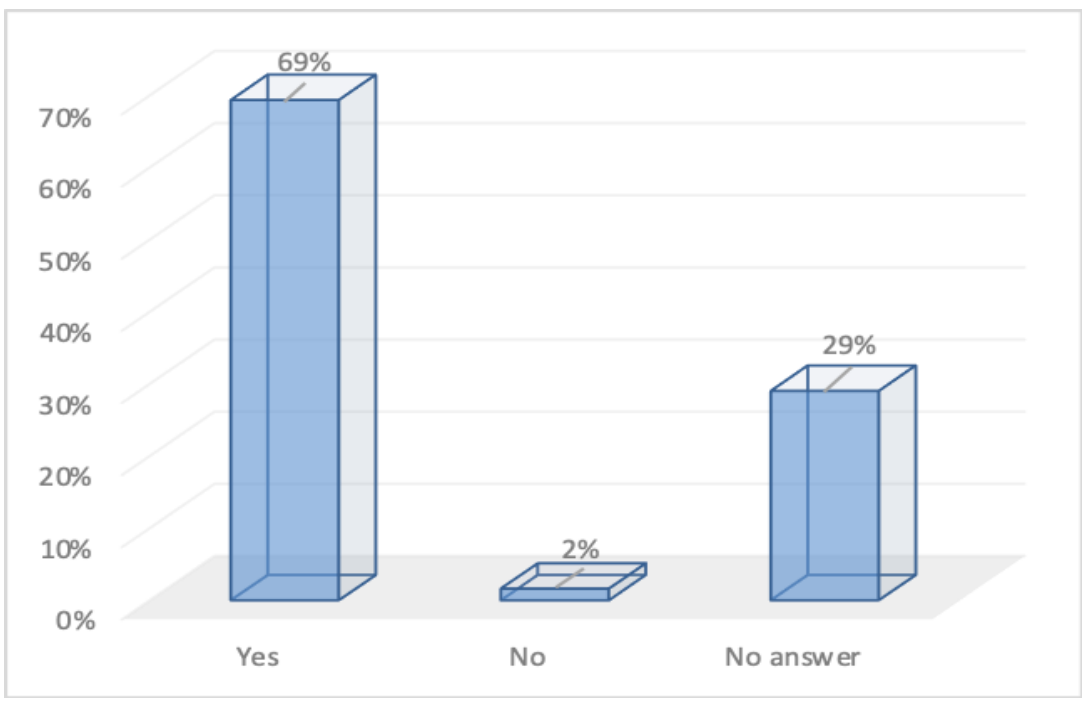

Source: author's calculations based on survey

Fig. 6. Question 6. Do you think the economic situation of your company has improved since the enactment of "Law of Mountain"? 


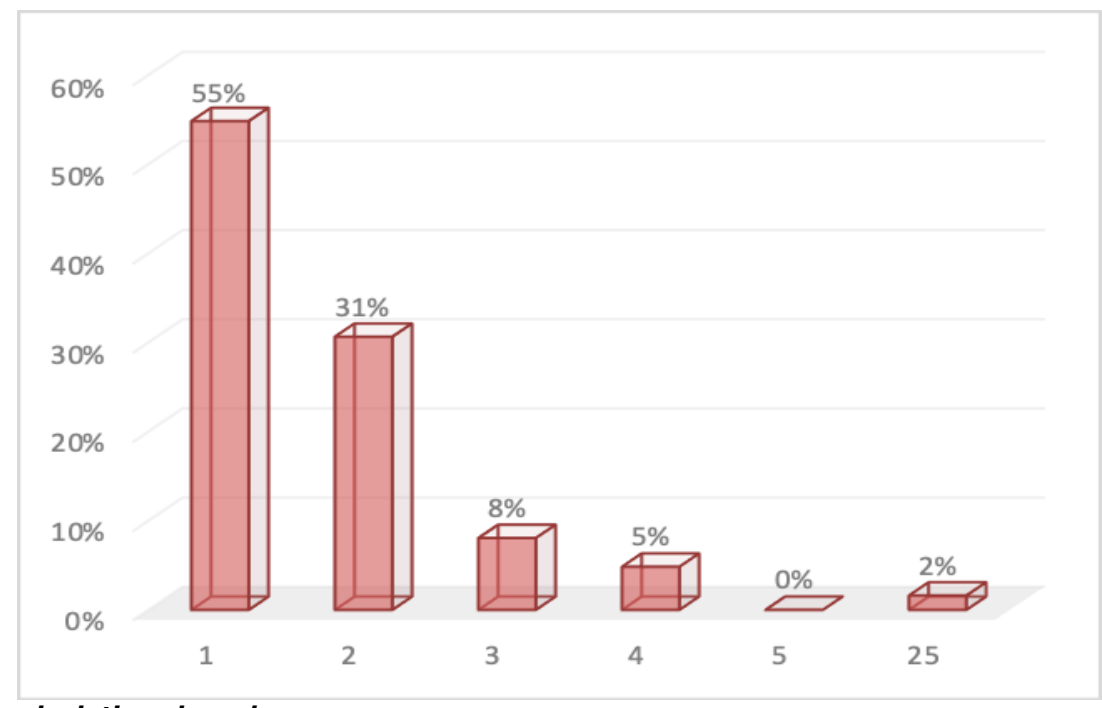

Source: author's calculations based on survey

Fig. 7. Question 7. How many employees do you have?

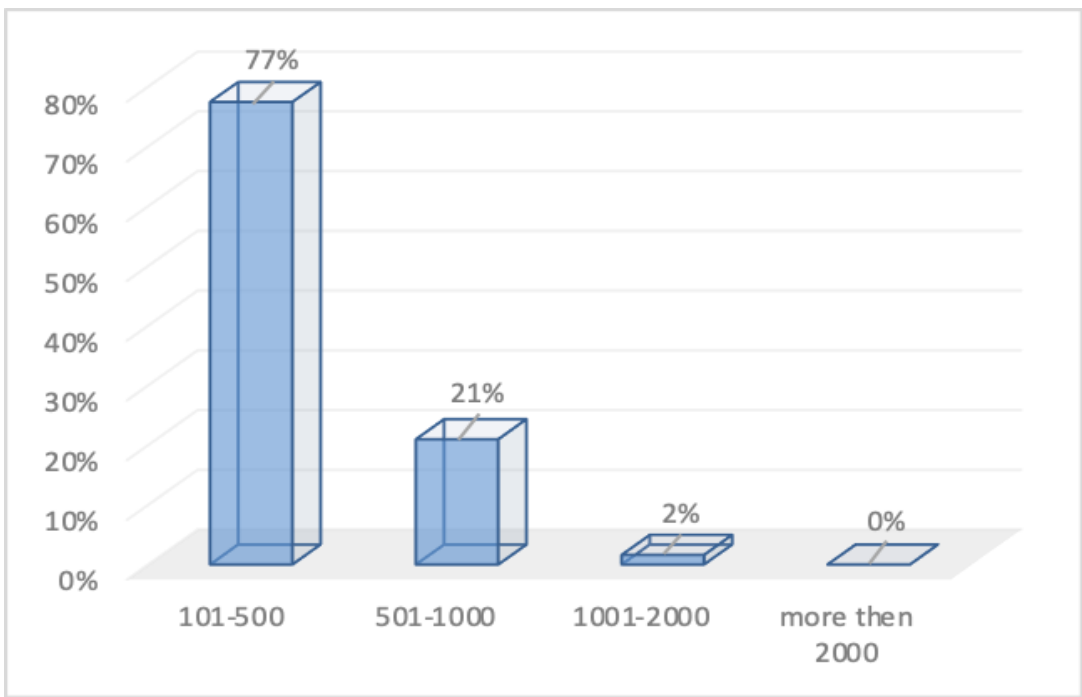

Source: author's calculations based on survey

Fig. 8. Question 8. Monthly income of employees

\section{Acknowledgement}

The research is carried out within the framework of Targeted Scientific Research Project of Batumi Shota Rustaveli State University "Impact of Internal Migration on Some Economic Parameters of the Autonomous Republic of Adjara" (on the example of Khulo municipality).

\section{Bibliography}

1. "Georgia Migration Profile" (2017). Principal Commission on Migration Issues, Tbilisi (In Georgian).

2. "Problems with demography and sociology" (2017). Collection of Proceedings. Ilia State University, Institute of Demography and Sociology, Tbilisi.

3. National Statistic Office of Georgia (2020). http://www.geostat.ge/

4. SPLASH-db.eu (2015): Policy: "Migration Policies: Latvia" (Information provided by Elina ApsiteBerina). https://splash-db.eu

5. Law of Georgia on Development of Highland Regions (In Georgian).

6. Totadze, A (2012). "Adjara Population". Publishing house "Universal" Tbilisi.

7. Tsiklashvili, N., Tchanidze, K., Surmanidze, Z (2019). "The Process of Internal Migration of the Adjarian Highlands To The Modern Stage". The institute for the research of economic and social problems of globalization, Tbilisi.

8. Tsuladze, G., Sulaberidze, A (2016). "Demographic Characteristics of Georgian Regions", Ilia State University, Institute of Demography and Sociology, Tbilisi. 